\title{
JOURNAL.RU
}

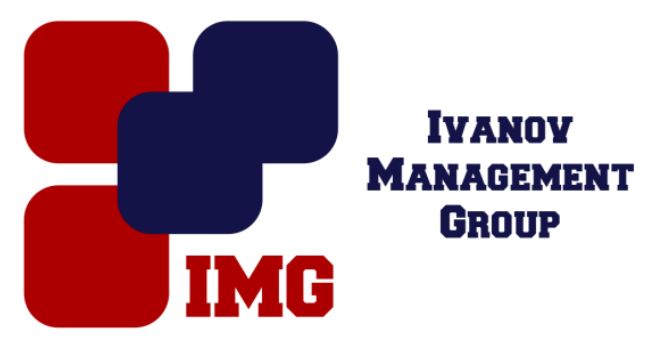

Демин В.И., Ригер Т.В., Ломоносова Д.В. Кубанский государственный технологический университет Краснодар, Россия

doi: 10.18411/1j-30-06-2017-10

idsp 000001:1j-30-06-2017-10

\section{О результатах анализа производственного травматизма на предприятиях строительной отрасли}

\section{Аннотация}

Строительная отрасль является одной из наиболее опасных отраслей производства. В работе перечислены вредные и опасные производственные факторы, воздействующие на работников строительной отрасли. Приведены результаты исследований международной организацией OSHA. рассмотрены данные государственной статистики по занятости в строительной отрасли. Проведен анализ несчастных случаев со смертельным исходом в строительстве, который позволил выделить наиболее частые виды происшествий. По результатам анализа производственного травматизма в Краснодарском крае выявлены основные причины несчастных случаев в строительной отрасли.

Сделан вывод о необходимости повышение эффективности СУОТ на предприятиях строительной отрасли.

Ключевые слова: опасные и вредные производственные факторы, охрана труда, система управления охраной труда (СУОТ), коэффициент смертельного травматизма, производственный травматизм, условия труда.

Строительная отрасль является одной из наиболее опасных отраслей производства. Особенностями работы в строительной отрасли являются: мобильность и временность места работ, производство работ подрядчиками и субподрядчиками, работа в условиях неблагоприятного климата, на высоте, тяжесть и напряженность работы, воздействие опасных и вредных 
производственных факторов, таких как шум, вибрация, температура, пыль и других [1,2].

По данным Occupational Safety \& Health Administration (OSHA) строительный сектор в Европе имеет одни из худших показателей безопасности и гигиены труда среди других сфер производства. Рабочие в строительном секторе испытывают большее воздействие биологических, химических и эргономических факторов риска, а также шума и температуры, чем в других отраслях.

В исследованиях, проведенных OSHA, выявлено следующее:

- около 45 \% строительных рабочих говорят, что их работа влияет на их здоровье;

- строительство является одним из секторов экономики с наиболее тяжелыми физическими нагрузками;

- экономические потери от несчастных случаев и заболеваний в строительном секторе огромные для физических лиц, работодателей и правительства;

- более 99 \% строительных фирм в Европе являются малыми и средними предприятиями.

В соответствии с директивами Европейского Союза (ЕС), работодатели несут ответственность за здоровье и безопасность своих работников. Директива ЕС №89/391 обеспечивает общую основу для здоровья и безопасности, управления и оценки рисков. Работодатели обязаны оценивать риски и принимать практические меры для защиты безопасности и здоровья своих работников, вести учет аварий, предоставлять информацию и обучение, осуществлять консультации сотрудников, координировать разрабатываемые меры с подрядчиками.

По данным, опубликованным Федеральной службой государственной статистики, на 30 ноября 2015 года в России было зарегистрировано 226838 строительных организаций, из них - 223022 являлись частными, 818 имели государственную форму собственности, 405 - смешанную российскую, 395 являлись муниципальными.

Среднегодовая численность занятых в строительстве в 2015 году составила 5820,6 тыс. человек. Из всей численности работников строительных организаций, занятых во вредных и опасных условиях труда, 37,4\% работают в условиях, не отвечающих гигиеническим нормативам условий труда. 
На тяжелых работах занято 20,1 \% работников, 7,5 \% - занято на работах, связанных с напряженностью трудового процесса.

В России особенно высок уровень смертельного травматизма в строительной отрасли, который в последние годы является достаточно стабильным. Самое печальное то, что число смертельных случаев остается практически постоянным и очень высоким, что говорит о неудовлетворительной работе или отсутствии системы управления охраной труда (СУОТ) на всех уровнях $[3,4]$.

Строительство относится к наиболее травмоопасным отраслям экономики. Коэффициент частоты травматизма в строительстве равен 5, а в отдельных видах работ (земляные и подземные работы, монтажные работы и др.) превышает и этот показатель. Высокий уровень травматизма можно объяснить спецификой выполнения строительных работ: временным характером рабочих мест, необходимостью выполнения работ повышенной опасности, на высоте, в сложных климатических условиях и т.д.

Анализ несчастных случаев со смертельным исходом в строительстве позволяет выделить наиболее частые виды происшествий:

- падение пострадавшего с высоты (24,3 \%);

- дорожно-транспортные происшествия (22,1\%);

- падения, обрушения, обвалы предметов, материалов, земли (14,1%).

При изучении причин несчастных случаев со смертельным исходом в строительных организациях было установлено, что свыше 60 \% причин носят организационный характер.

Согласно статистических данных Министерства труда и социального развития Краснодарского края наибольшее число пострадавших зарегистрировано в организациях: оптовой и розничной торговли, ремонта автотранспортных средств, мотоциклов, бытовых изделий и предметов личного пользования - 236 работников, обрабатывающих производств - 185 работников, транспорта и связи - 139 работников, строительства - 117 работников, здравоохранения и предоставления социальных услуг - 91 работник, сельского хозяйства, охоты и лесного хозяйства - 75 работников.

Исходя из анализа мониторинга, проводимого министерством, следует отметить, что по сравнению с 2014 годом возросло число пострадавших от несчастных случаев на производстве в организациях строительства с 86 до 117 работников. 
Как показывает анализ, уровень смертельного травматизма в расчете на 1000 работающих (коэффициент смертности) по сравнению с прошлым годом увеличился на 2,4 \% и составил 0,043 (за 12 месяцев 2014 года - 0,042).

Выше среднекраевого значения $(0,043)$ коэффициент смертельного травматизма на 1000 работающих зафиксирован в организациях добычи полезных ископаемых (0,206), строительства $(0,182)$, производства и распределения электроэнергии, газа и воды $(0,135)$, сельского хозяйства, охоты и лесного хозяйства $(0,106)$, транспорта и связи $(0,087)$ и обрабатывающих производств (0,071).

Анализ производственного травматизма, проводимый Государственной инспекцией труда Краснодарского края, позволяет сделать выводы о том, что основными причинами несчастных случаев являются:

- неудовлетворительная организация производства работ;

- нарушение правил дорожного движения;

- неудовлетворительное содержание и недостатки в организации рабочих мест;

- неприменение работником средств индивидуальной защиты вследствие необеспеченности ими работодателем.

Относительно высок уровень травматизма по причине «нарушение работником трудового распорядка и дисциплины труда».

Государственная инспекция труда Краснодарского края в отчете о своей деятельности за 2015 год указала, что нарушения, выявляемые в строительных организациях, в основном касаются несоблюдения трудового законодательства по вопросам обучения и инструктирования работников по охране труда (OT), проведения специальной оценки условий труда, расследования, оформления и учета несчастных случаев на производстве.

Таким образом, анализируя ситуацию в строительной сфере, можно отметить, что проблемы в этой области производства сохраняются и в России, и в Европейских странах. Есть свои особенности в организации СУОТ и в Европе, в частности, наибольшее внимание уделяется безопасности и здоровью работающего в строительной отрасли. В России же на первое место ставится решение проблемы качества и безопасности строительных объектов (продукции) для дальнейшей эксплуатации потребителем.

Несмотря на то, что согласно классификации видов экономической деятельности по классам профессионального риска, утвержденной приказом Министерства здравоохранения и социального развития РФ от 18 декабря 2006 
года № 857, большинство строительных работ относятся к классу 8-9 (из 32), созданы саморегулирующие организации (СРО), национальное объединение строителей (НОСТРОЙ), осуществляется нормативная поддержка со стороны государства в виде разработки и издания нормативных актов, в том числе и по ОТ, организована СУОТ на предприятиях, статистические данные продолжают говорить о строительной отрасли, как об одной из неблагополучных в сфере безопасности труда.

Наряду с другими причинами, обусловливающими проблемы строительной сферы, отсутствие системного подхода или бездействие СУОТ на предприятии препятствует развитию и поддержанию культуры безопасного труда, а дефицит этой культуры у работников увеличивает влияние человеческого фактора на возникновение аварий или происшествий на производстве.

К сожалению, производство строительных работ сопряжено с воздействием опасных факторов, которые невозможно устранить полностью, или уменьшить степень их воздействия на работника до нормативных значений.

Поэтому одной из задач, касающейся сохранения жизни, здоровья и безопасности, и содействующей исправлению неблагоприятной ситуации в строительной отрасли, является повышение эффективности СУОТ [5,6,7,8].

Сегодня не следует доказывать тот факт, что проблема экономической безопасности строительной организации зависит не только от финансовой безопасности, но и от надежности производственных процессов и ОТ ее работников. Мировой опыт свидетельствует, что высокий травматизм и аварийность на строительных объектах, незащищенность работника и собственности несовместимы с высокой конкурентоспособностью организации. 
1. Ригер Т.В., Сапрыкина Н.В., Демин В.И., Козак Д.А. Идентификация опасностей производственного процесса на предприятиях строительной отрасли// Научные труды КубГТУ: электрон. сетевой политематич. журн. 2016. № 5 . URL: http://ntk.kubstu.ru/file/953.

2. Берсекова В.И. О состоянии охраны труда в организациях строительной отрасли/ Берсекова В.И., Рыжкова А.А., Ригер Т.В., Демин В.И.// Научные труды КубГТУ: электрон. сетевой политематич. журн. 2017. № 1. URL: http://ntk.kubstu.ru/file/1328.

3. Демин В.И. Состояние производственного травматизма на малых предприятиях/ Демин В.И., Ригер Т.В., Сапрыкина Н.В.//В сборнике Природноресурсный потенциал, экология и устойчивое развитие регионов России: сборник статей XIII Международной научно-практической конференции. Под общей редакцией Селезнева В.А., Лушкина И.А. МНИЦ ПГСХА. - Пенза: РИО ПГСХА, 2015. - с. 22 - 25.

4. Ригер Т.В. Методика оценки профессионального риска методом использования коэффициента безопасности труда/ Ригер Т.В., Сапрыкина Н.В., Демин В.И., Норман Л.В.// Научные труды КубГТУ: электрон. сетевой политематич. журн. 2016. № 5. URL: http://ntk.kubstu.ru/file/960.

5. Ригер Т.В. Опыт внедрения системы управления охраной труда на различных предприятиях/ Ригер Т.В., Сапрыкина Н.В., Демин В.И., Власенко Н.В.// Научные труды КубГТУ: электрон. сетевой политематич. журн. 2015. № 10. URL: http://ntk.kubstu.ru/file/545.

6. Ригер Т.В. Разработка системы управления охраной труда на малых предприятиях пищевого профиля/ Ригер Т.В., Сапрыкина Н.В., Демин В.И., Истошина Н.Ю.// Известия высших учебных заведений. Пищевая технология, 2016. № 1. - с. 113-117.

7. Ригер Т.В. Система управления охраной труда вуза/ Ригер Т.В., Демин В.И., Сапрыкина Н.В.//В сборнике Дальневосточная Весна-2014: сборник статей 12-й Международной научно-практической конференции по проблемам экологии и безопасности. Под редакцией И.П. Степановой И.П., Никифоровой Г.Е. Комсомольск-на-Амуре: ФГБОУ ВПО «КнАГТУ», 2014. - с. 120-123.

8. Демин В.И. Опыт разработки системы управления охраной труда в вузе/Демин В.И., Ригер Т.В., Сапрыкина Н.В.//В сборнике Экология и безопасность жизнедеятельности: сборник статей XIV Международной научно-практической конференции. Под общей редакцией Селезнева В.А., Лушкина И.А. МНИЦ ПГСХА. - Пенза: РИО ПГСХА, 2014. - c. $31-33$. 